\title{
InVESTigation of the FleXibiLity of Bronchoscopes
}

\author{
K.-J. Franke, C. Bruckner, G. Nilius, K.-H. Ruhle \\ Department of Pneumology and Critical Care Medicine, Helios Klinik Ambrock, University of Witten/Herdecke, Germany
}

\begin{abstract}
Objective: For transbronchial biopsy of peripheral pulmonary lesions manouevering the biopsy instrument into acutely angulated subsegmental ostia is frequently problematic. The aim of the present study was to compare the stiffness of various biopsy instruments with regard to their use in the clinical setting.

Methods: The maximal anterograde and retrograde bending angles, were measured for various bronchoscopes and biopsy instruments. Measurement was made with the distal tip of the biopsy instrument either flush with the distal end of the bronchoscope, or extending $1.5 \mathrm{~cm}$ beyond it. The following scopes and biopsy instruments were investigated: 1 . the $6.2 \mathrm{~mm}$ outside diameter (OD) bronchoscope, with the 2.4 $\mathrm{mm}$ OD forceps, $0.7 \mathrm{~mm}$ needle, $2.3 \mathrm{~mm}$ catheter, and the $1.9 \mathrm{~mm}$ cryoprobe. 2. the $5.1 \mathrm{~mm}$ OD bronchoscope, with the $1.8 \mathrm{~mm}$ forceps, $0.7 \mathrm{~mm}$ needle, and the $1.8 \mathrm{~mm}$ catheter. 3 . the $3.7 \mathrm{~mm}$ bronchoscope, with the $1.0 \mathrm{~mm}$ forceps and the $0.8 \mathrm{~mm}$ forceps.

Results: Maximum angulation was greater by $35.4^{\circ}$ with the needle extended, vis-à-vis the needle "flush". Both needle and catheter were associated with a greater angulation of up to $20.5^{\circ}$ in comparison with the forceps. With an instrument in the working channel the largest anterograde angles were measured for the $5.1 \mathrm{~mm}$ bronchoscope, and the largest retrograde angles for the $6.2 \mathrm{~mm}$ bronchoscope.

Conclusion: When selecting the optimal instrument for transbronchial biopsy specimen collection, account must be taken of the fact that the degree of angulation will depend on the type and diameter of the instrument employed.
\end{abstract}

Key words: Transbronchial biopsy, lung cancer, angulation of biopsy instruments, needle aspiration, catheter aspiration, cryobiopsy

\section{INTRODUCTION}

For the diagnostic workup of peripheral carcinoma of the lung employing flexible bronchoscopy, various instruments are available for transbronchial specimen collection [1-2]. To obtain histological material, transbronchial forceps biopsy (TBB) is employed. Although it is known that the latest technique of cryobiopsy can provide large histological specimens of good quality, no relevant data are currently available for peripheral pulmonary lesions [3-4]. Both transbronchial needle aspiration (TBNA) and transbronchial catheter aspira- tion (TBCA) are cytological techniques which with regard to malignant lesions have a "hit rate" higher by at least 15\% vis-à-vis forceps biopsy [5-7].

Needle aspiration has the advantage that it can also be applied to extrabronchial processes, such as, for example, haematogenic metastases [8]. In contrast to forceps biopsy, TBCA enables material to be collected not merely directly from the lesion itself, but also from its immediate neighbourhood [9]. Apart from the specific material collection properties of the biopsy instrument, its stiffness, which modifies the bendability of the bronchoscope, is a further major determinative factor with an influence on diagnostic sensitivity. Owing to the pressure-volume relationship in the lungs during inspiration, most carcinomas are localised in the upper lobes. The sharply acute angles met with in the apical upper lobe segments, however, often make it impossible to deploy the biopsy instruments a difficulty also encountered in the apical lower lobe segments. For the same reason also, biopsy collection from peripheral lesions under endobronchial ultrasound guidance in the apical upper lobe segments has a lower hit rate than for other locations - with the added risk of damage to the US probe [10-11].

With the aim of facilitating the choice of the most suitable biopsy instrument and bronchoscope diameter for the specific clinical task in hand, the present experimental bronchoscope study compared the maximum angulation of various combinations of scopes and instruments.

\section{Material And Methods}

The stiffness of the biopsy instruments was determined by measuring the maximum bending angle of the distal end of the bronchoscope (Fig. 1). Measurements were made for each experimental situation and for both anterograde (up) and retrograde (down) angulation, and the respective means of 10 measurements compared.

We performed our measurements on 3 video bronchoscopes (Pentax Europe, Hamburg, Deutschland), each with a different outside diameter. The angles were measured first without, and then with, the respective biopsy instrument in the working channel. The distal tip of the biopsy instrument was either flush with the distal end of the bronchoscope ("flush"), or projected $1.5 \mathrm{~cm}$ beyond it $(1.5 \mathrm{~cm})$. The $1.5 \mathrm{~cm}$ was determined the length of the needle employed $(1.3 \mathrm{~cm})$. 
The following combinations of bronchoscopes and biopsy instruments were investigated :

1. Video endoscope (VE) outside diameter (OD) 6.2 $\mathrm{mm}$ (working channel diameter $2.8 \mathrm{~mm}$ ); instruments: biopsy forceps OD $2.4 \mathrm{~mm}$ (oval; Pentax Europe, Hamburg, Germany); cryoprobe OD 1.9 mm (Erbe, Tübingen, Germany); transbronchial biopsy needle OD $0.7 \mathrm{~mm}$ (OD needle sheath 1.8 $\mathrm{mm}$, needle length $13 \mathrm{~mm}$; Endo-Technik, Solingen, Germany); Aspiration catheter OD $2.3 \mathrm{~mm}$ (Wieser, Egenhofen, Germany).

2. Video endoscope (VE) outside diameter (OD) 5.1 $\mathrm{mm}$ (working channel diameter $2.0 \mathrm{~mm}$ ); instruments: disposable biopsy forceps OD $1.8 \mathrm{~mm}$ (oval; Medwork, Höchstadt/Aisch, Germany); transbronchial biopsy needle OD $0.7 \mathrm{~mm}$ (OD needle catheter $1.8 \mathrm{~mm}$, needle length $13 \mathrm{~mm}$; Endo-Technik, Solingen, Germany); aspiration catheter OD $1.8 \mathrm{~mm}$ (Wieser, Egenhofen, Germany).

3. Video endoscope (VE) outside diameter (OD) 3.7 $\mathrm{mm}$ (working channel diameter $1.2 \mathrm{~mm}$ ); instrument: biopsy forceps OD $1.0 \mathrm{~mm}$ (oval; MTW, Wesel, Germany); biopsy forceps OD $0.8 \mathrm{~mm}$ (oval; Endo-Passion, Dürbheim, Germany).

Each of the bronchoscopes used in the experiment had previously been employed in approximately 500 clinical examinations.

\section{RESULTS}

The angles measured are shown in Table 1.

Bronchoscope without biopsy instrument

For anterograde angulation measurement with no instrument in the channel, angles were smaller by between $6.1^{\circ}$ (VE OD $3.7 \mathrm{~mm}$ ) and $23.1^{\circ}$ (VE OD 6.2 $\mathrm{mm}$ ), and for retrograde angulation smaller by between $14.7^{\circ}$ (VE OD $3.7 \mathrm{~mm}$ ) and $19.3^{\circ}$ (VE OD 6.2 $\mathrm{mm})$ - vis-a-vis the manufacturer's specification for maximum angulation.

Biopsy instruments "flush" and extended $(1.5 \mathrm{~cm})$

On extending the biopsy instrument, an additional increase in the anterograde angle of $11.4^{\circ}$ (VE OD 6.2 $\mathrm{mm}$ ) and $35.4^{\circ}$ (VE OD $5.1 \mathrm{~mm}$ ) was obtained for the needle; while for the catheter the increase was anterograde $16.6^{\circ}$ and retrograde $8.2^{\circ}$ (VE OD $6.2 \mathrm{~mm}$ ).

\section{Comparison of biopsy instruments (VE OD $6.2 \mathrm{~mm}$ )}

In the extended option, all instruments were associated with larger angles - both up and down. For needle and catheter in comparison with forceps and cryoprobe the respective measurements were anterograde $148.4^{\circ} / 149.9^{\circ}$ versus $132.3^{\circ} / 121.9^{\circ}$ and retrograde $108.3^{\circ} / 110.1^{\circ}$ versus $95.7^{\circ} / 88.6^{\circ}$ - that is, an appreciably greater angulation. With needle or catheter in the channel the difference vis-à-vis angulation without

Table 1. Maximum angulation of biopsy instruments. The distal tip was either flush with the distal end of the bronchoscope (flush) or extended $1.5 \mathrm{~cm}$ beyond it $(1.5 \mathrm{~cm})$. Angles were recorded as means \pm standard deviation of 10 measurements. OD = outside diameter.

\begin{tabular}{|c|c|c|c|c|}
\hline $\begin{array}{l}\text { Maximum } \\
\text { Angulation }\left[{ }^{\circ}\right]\end{array}$ & $\begin{array}{l}\text { Anterograde } \\
\text { Instruments flush }\end{array}$ & $\begin{array}{l}\text { Anterograde } \\
\text { Instruments } 1.5 \mathrm{~cm}\end{array}$ & $\begin{array}{l}\text { Retrograde } \\
\text { Instruments flush }\end{array}$ & $\begin{array}{l}\text { Retrograde } \\
\text { Instruments } 1.5 \mathrm{~cm}\end{array}$ \\
\hline $\begin{array}{l}\text { Bronchoscope alone } \\
O D 6.2 \mathrm{~mm}\end{array}$ & $156.9 \pm 3.1$ & & $110.7 \pm 4.3$ & \\
\hline $\begin{array}{l}\text { with forceps } \\
\text { OD } 2.4 \mathrm{~mm}\end{array}$ & $129.1 \pm 2.8$ & $132.3 \pm 3,3$ & $96.9 \pm 2.7$ & $95.7 \pm 1.5$ \\
\hline $\begin{array}{l}\text { with needle } \\
\text { OD } 0.7 \mathrm{~mm}\end{array}$ & $137.0 \pm 3.0$ & $148.4 \pm 3.1$ & $103.9 \pm 3.1$ & $108.3 \pm 1.7$ \\
\hline $\begin{array}{l}\text { with catheter } \\
\text { OD } 2.3 \mathrm{~mm}\end{array}$ & $133.3 \pm 1.7$ & $149.9 \pm 2.0$ & $101.9 \pm 2.4$ & $110.1 \pm 2.3$ \\
\hline $\begin{array}{l}\text { with cryoprobe } \\
\text { OD } 1.9 \mathrm{~mm}\end{array}$ & $119.5 \pm 3.5$ & $121.9 \pm 1.6$ & $82.5 \pm 2.7$ & $88.6 \pm 1.1$ \\
\hline $\begin{array}{l}\text { Bronchoscope alone } \\
O D 5.1 \mathrm{~mm}\end{array}$ & $203.0 \pm 2.0$ & & $113.6 \pm 1.7$ & \\
\hline $\begin{array}{l}\text { with forceps } \\
\text { OD } 1.8 \mathrm{~mm}\end{array}$ & $176.6 \pm 3.6$ & $167.0 \pm 3.3$ & $92.9 \pm 2.2$ & $90.7 \pm 2.9$ \\
\hline $\begin{array}{l}\text { with needle } \\
\text { OD } 0.7 \mathrm{~mm}\end{array}$ & $145.1 \pm 3.6$ & $180.5 \pm 2.6$ & $86.3 \pm 2.1$ & $102.3 \pm 2.0$ \\
\hline $\begin{array}{l}\text { with catheter } \\
\text { OD } 1.8 \mathrm{~mm}\end{array}$ & $190.1 \pm 3.0$ & $187.5 \pm 3.8$ & $99.9 \pm 2.3$ & $100.8 \pm 1.4$ \\
\hline $\begin{array}{l}\text { Bronchoscope alone } \\
O D 3.7 \mathrm{~mm}\end{array}$ & $203.9 \pm 2.1$ & & $105.3 \pm 1.1$ & \\
\hline $\begin{array}{l}\text { with forceps } \\
\text { OD } 0.8 \mathrm{~mm}\end{array}$ & $162.0 \pm 3.7$ & $157.3 \pm 2.4$ & $84.6 \pm 2.0$ & $90.6 \pm 1.4$ \\
\hline $\begin{array}{l}\text { with forceps } \\
\text { OD } 1.0 \mathrm{~mm}\end{array}$ & $143.2 \pm 6.1$ & $141.4 \pm 3.1$ & $64.3 \pm 2.3$ & $64.3 \pm 1.0$ \\
\hline
\end{tabular}




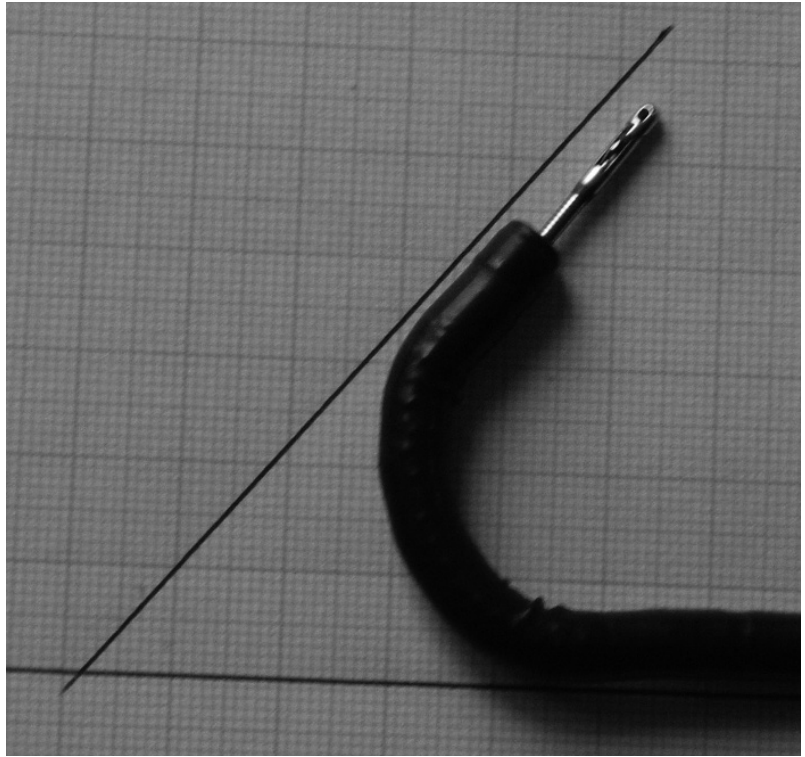

Fig. 1. Angle measurement at maximum anterograde angulation. Bronchoscope with outside diameter (OD) $6.2 \mathrm{~mm}$, the biopsy forceps (OD $2.4 \mathrm{~mm}$ ) is extended $1.5 \mathrm{~cm}$ beyond the distal end of the bronchoscope. That part of the of the bronchoscope, which cannot actively be angulated, lies along the baseline.

biopsy instrument was: minimum $0.6^{\circ}$ (retrograde, catheter) and maximum $8.5^{\circ}$ (anterograde, needle).

\section{Comparison of the biopsy instruments (VE OD $5.1 \mathrm{~mm}$ )}

The extended needle and catheter were both associated with a clearly greater angulation in comparison with forceps, namely: anterograde $180.5^{\circ} / 187.5^{\circ}$ versus $167.0^{\circ}$ and retrograde $102.3^{\circ} / 100.8^{\circ}$ versus $90.7^{\circ}$. In comparison with the flush instrument, extension of the forceps was associated with a decrease in anterograde angulation of $9.6^{\circ}$.

\section{Comparison of the biopsy instruments (VE OD $3.7 \mathrm{~mm}$ )}

In the extended state a clearly greater angulation, both anterograde and retrograde, was achieved with the forceps OD $0.8 \mathrm{~mm}$ in comparison with the forceps OD $1.0 \mathrm{~mm}$, namely $157.3^{\circ} / 90.6^{\circ}$ versus $141.4^{\circ} / 64.3^{\circ}$, respectively.

\section{Comparison of the bronchoscopes}

The largest anterograde angle with biopsy instrument in the working channel was measured with the VE OD $5.1 \mathrm{~mm}$ for needle and catheter $\left(180.5^{\circ}\right.$ and $\left.190.1^{\circ}\right)$, and retrograde with the VE OD $6.2 \mathrm{~mm}$, again for needle and catheter $\left(108.3^{\circ}\right.$ and $\left.110.1^{\circ}\right)$. The anterograde angles measured for the VE OD $3.7 \mathrm{~mm}$ with forceps in the channel were at least $9.7^{\circ}$ smaller than those measured for the VE OD $5.1 \mathrm{~mm}$, and the retrograde angles at least $5.1^{\circ}$ smaller than those measured for the VE OD $6.2 \mathrm{~mm}$.

\section{Discussion}

Wear of the bronchoscopes

The angulation of the bronchoscope without a biopsy instrument was less by a maximum of $23.1^{\circ}$ than that specified by the manufacturer. The latter expect that major repairs will be needed after some 1,500 examinations. Although the 'scopes employed in our investigation had been used in the clinical setting on only some 500 occasions, this sufficed to reduce their angulation properties.

\section{Advantage of extending the biopsy instrument}

When the biopsy instrument is extended beyond the end of the channel greater angulation is achieved - for the VE OD $6.2 \mathrm{~mm}$ up to $16.6^{\circ}$ with needle and catheter, and for the VE OD $5.1 \mathrm{~mm}$ up to. $35.4^{\circ}$ with the needle (Table 1). The reason is, of course, the fact that the metallic needle is comparatively inflexible. Since the identical needle (OD $0.7 \mathrm{~mm}$, OD of the needle sheath1 $1.8 \mathrm{~mm}$ ) was used with both bronchoscopes, the smaller-calibre bronchoscope showed a greater difference between flush and extended - as might be expected. With regard to the catheter however, a difference was seen only for the $2.3 \mathrm{~mm}$ catheter (OD), but not for the $1.8 \mathrm{~mm}$ catheter, the stiffness of which is appreciably less. The distal end of the $2.3 \mathrm{~mm}$ catheter is stiffer than the shaft (Fig. 2a), which explains the difference between flush and extended.

Maximum angulation was seen with needle and catheter In comparison with forceps and cryoprobe, the largest increase in maximum angulation - up to $28^{\circ}$ anterograde, and up to $11.6^{\circ}$ retrograde - was measured with needle and catheter (Table 1 ).

Both the catheter and the plastic sheath enclosing and guiding the needle are less stiff than the metal instruments themselves. This can clearly be seen on further extending the biopsy instrument (catheter, forceps, needle) beyond the working channel of the bronchoscope (Fig. 2a-c).

The largest angulation is seen with the $5.1 \mathrm{~mm}$ bronchoscope Comparison of the bronchoscopes with biopsy instruments in the working channel revealed the largest anterograde angulation for the VE OD $5.1 \mathrm{~mm}$ - maximum $190.1^{\circ}$ - and the largest retrograde angulation for the VE OD $6.2 \mathrm{~mm}$ - maximum $110.1^{\circ}$ - again measured with needle or catheter in the channel (Table 1).

While the manufacturer's specifications with working channel empty indicate a larger anterograde angulation for the VE OD $5.1 \mathrm{~mm}\left(210^{\circ}\right)$ than for the VE OD $6.2 \mathrm{~mm}\left(180^{\circ}\right)$, the larger angulation also seen with needle or catheter in the channel is due to the fact that in the case of the VE OD $5.1 \mathrm{~mm}$ the same needle in a small-calibre sheath (OD $1.8 \mathrm{~mm}$ ), and the small-calibre aspiration catheter (OD $1.8 \mathrm{~mm}$ ) were used. The explanation of the fact that retrograde angulation with no biopsy instrument in the channel is equal $\left(130^{\circ}\right)$ for both VE OD $5.1 \mathrm{~mm}$ and VE OD 6.2 $\mathrm{mm}$, is that the VE OD $6.2 \mathrm{~mm}$ 'scope is provided with a stronger bending control wire capable of exerting a greater traction against the greater resistance of the catheter with the larger outside diameter. For the same reason, angulation of the VE OD $3.7 \mathrm{~mm}$ (anterograde angulation $210^{\circ}$, retrograde $130^{\circ}$ ) with forceps in the working channel is smaller than that of the CE OD $5.1 \mathrm{~mm}$ (Table 1). For the former bronchoscope only mini-forceps are available. 

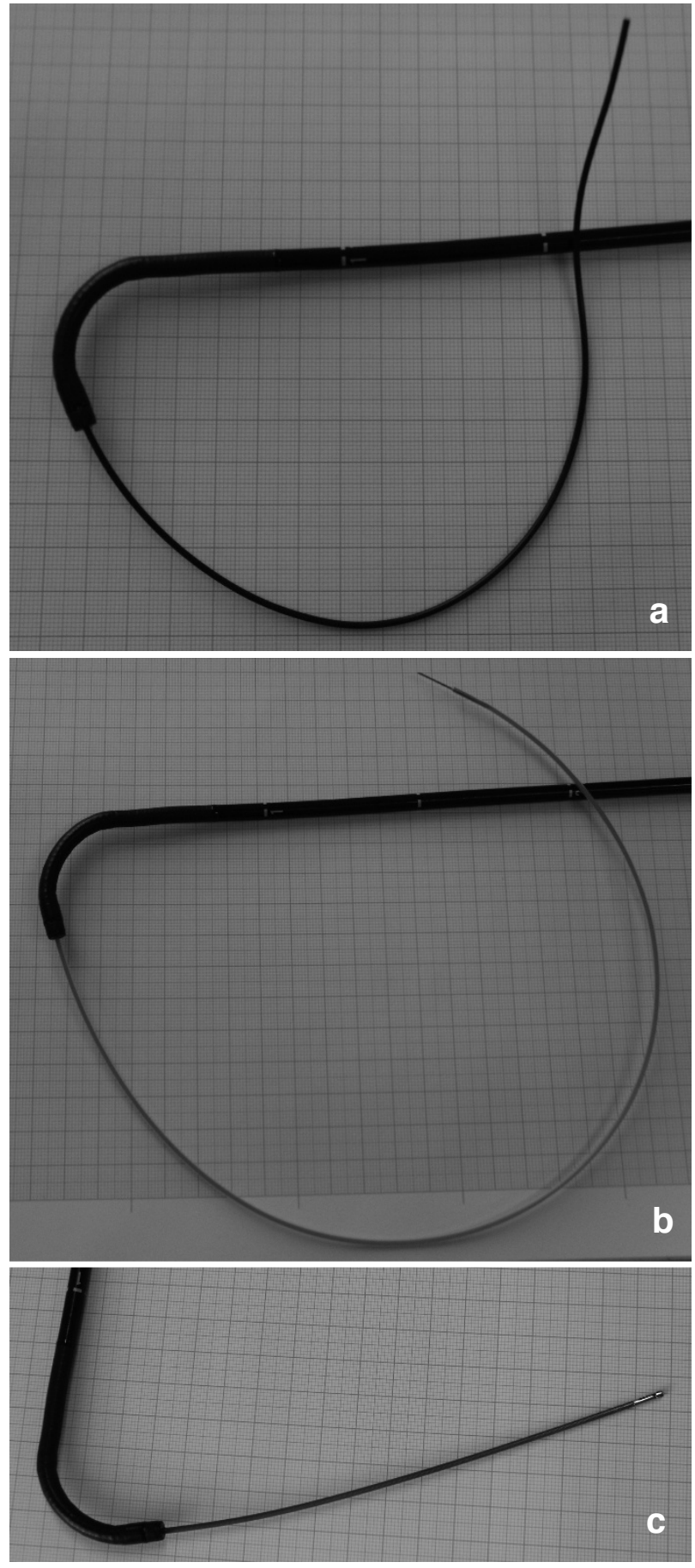

Fig. 2a-c. The biopsy instrument is extended beyond the working channel in retrograde angulation (VE OD $6.2 \mathrm{~mm}$ ). The forceps (OD $2.4 \mathrm{~mm}$ ) (2c) is associated with an appreciably smaller angulation than the needle (needle sheath OD 1.8 $\mathrm{mm})(2 \mathrm{~b})$ or aspiration catheter (OD $2.3 \mathrm{~mm})(2 \mathrm{a})$. The curvature in the catheter was shaped manually beforehand (2a).

\section{Clinical relevance}

In the diagnostic workup of peripheral pulmonary carcinoma, flexible bronchoscopy is of particular importance since surgery is often no longer an option, either because the tumour is too far advanced or the patient would not survive the operation [1,12-13]. 'Transbronchial biopsy also makes it possible to intubate acutely angled subsegmental ostia, for which purpose both anterograde and retrograde angulation is indispensible.

The largest angles with biopsy instrument in the working channel were measured for the catheter, and somewhat smaller - for the needle. Since, however, these instruments serve a cytological purpose, the diagnostic usefulness of the material thus obtained - in particular with regard to a need to identify an EGFRmutation - must be considered low [14]. On the other hand, the use of the cell block technique may be expected to improve the diagnosis - in particular in the case of the $2.3 \mathrm{~mm}$ catheter [15]. However, the CE OD $5.1 \mathrm{~mm}$ 'scope used with the $1.8 \mathrm{~mm}$ catheter or needle provides excellent anterograde angulation and can thus also be used. The option of pre-bending the distal end of the catheter prior to TBCA may - in comparison with TBB and TBNA - also promote further advancement and correct positioning of the catheter in the peripheral lung (Fig. 2a).

\section{CONCLUSION}

The appreciably better bending properties of catheter and needle in comparison with forceps, and possibly differences in the handling characteristics of the instruments in the periphery should be taken into account when preparing for a transbronchial biopsy.

Acknowledgments: The authors Karl-Josef Franke, Georg Nilius, Christiane Bruckner and Karl-Heinz Ruhle declare that no financial or other potential conflicts of interest exist in the subject matter.

\section{REFERENCES}

1. Chechani V. Bronchoscopic diagnosis of solitary pulmonary nodules and lung masses in the absence of endobronchial abnormality. Chest. 1996 Mar;109(3):620-5.

2. Bilaçeroglu S, Kumcuoglu Z, Alper H, Osma E, Cagirici U, Günel O, Bayol U, Celikten E, Perim K, Köse T. CT bronchus sign-guided bronchoscopic multiple diagnostic procedures in carcinomatous solitary pulmonary nodules and masses. Respiration. 1998;65(1):49-55.

3. Franke KJ, Theegarten D, Hann von Weyhern C, Nilius G, Brueckner C, Hetzel J, Hetzel M, Ruhle KH, Enderle MD, Szyrach MN. Prospective controlled animal study on biopsy sampling with new flexible cryoprobes versus forceps: evaluation of biopsy size, histological quality and bleeding risk. Respiration. 2010;80(2):127-32.

4. Babiak A, Hetzel J, Krishna G, Fritz P, Moeller P, Balli T, Hetzel M. Transbronchial cryobiopsy: a new tool for lung biopsies. Respiration. 2009;78(2):203-8.

5. Katis K, Inglesos E, Zachariadis E, Palamidas P, Paraskevopoulos I, Sideris G, Tamvakopoulou E, Apostolopoulou F, Rasidakis A. The role of transbronchial needle aspiration in the diagnosis of peripheral lung masses or nodules. Eur Respir J. 1995 Jun;8(6):963-6.

6. Gasparini S, Ferretti M, Secchi EB, Baldelli S, Zuccatosta L, Gusella P. Integration of transbronchial and percutaneous approach in the diagnosis of peripheral pulmonary nodules or masses. Experience with 1,027 consecutive cases. Chest. 1995 Jul;108(1):131-7.

7. Franke KJ, Nilius G, Rühle KH. [Transbronchial biopsy in comparison with catheter aspiration in the diagnosis of peripheral pulmonary nodules]. Pneumologie. 2006 Jan;60(1):7-10.

8. Shure D. Transbronchial biopsy and needle aspiration. Chest. 1989 May;95(5):1130-8. 
9. Franke KJ, Nilius G, Ruhle KH. Transbronchial catheter aspiration compared to forceps biopsy in the diagnosis of peripheral lung cancer. Eur J Med Res. 2009 Jan 28;14(1): 13-7.

10. Yoshikawa M, Sukoh N, Yamazaki K, Kanazawa K, Fukumoto S, Harada M, Kikuchi E, Munakata M, Nishimura $M$, Isobe $H$. Diagnostic value of endobronchial ultrasonography with a guide sheath for peripheral pulmonary lesions without X-ray fluoroscopy. Chest. 2007 Jun;131(6):1788-93.

11. Eberhardt R, Anantham D, Ernst A, Feller-Kopman D, Herth F. Multimodality bronchoscopic diagnosis of peripheral lung lesions: a randomized controlled trial. Am J Respir Crit Care Med. 2007 Jul 1;176(1):36-41.

12. Goeckenjan G, Sitter H, Thomas M, Branscheid D, Flentje M, Griesinger F, Niederle N, Stuschke M, Blum T, Deppermann KM, Ficker JH, Freitag L, Lübbe AS, Reinhold T, Späth-Schwalbe E, Ukena D, Wickert M, Wolf M, Andreas S, Auberger T, Baum RP, Baysal B, Beuth J, Bickeböller H, Böcking A, Bohle RM, Brüske I, Burghuber O, Dickgreber N, Diederich S, Dienemann H, Eberhardt W, Eggeling S, Fink T, Fischer B, Franke M, Friedel G, Gauler T, Gütz S, Hautmann H, Hellmann A, Hellwig D, Herth F, Heussel CP, Hilbe W, Hoffmeyer F, Horneber M, Huber RM, Hübner J, Kauczor HU, Kirchbacher K, Kirsten D, Kraus T, Lang SM, Martens U, Mohn-Staudner A, Müller KM, Müller-Nordhorn J, Nowak D, Ochmann U, Passlick B, Petersen I, Pirker R, Pokrajac B, Reck M, Riha S, Rübe C, Schmittel A, Schönfeld N, Schütte W, Serke M, Stamatis G, Steingräber M, Steins M, Stoelben E, Swoboda L, Teschler H, Tessen HW, Weber M, Werner A, Wichmann HE, Irlinger Wimmer E, Witt C, Worth $\mathrm{H}$. Prevention, diagnosis, therapy, and follow-up of lung cancer: interdisciplinary guideline of the German Respiratory Society and the German Cancer Society. Pneumologie. 2011 Jan;65(1):39-59.
13. Chhajed PN, Tamm M. Bronchoscopy for small pulmonary nodules and mediastinal staging of lung cancer: just do it! Am J Respir Crit Care Med. 2006 Nov 1; 174(9):961-2.

14. Mok TS, Wu YL, Thongprasert S, Yang CH, Chu DT, Saijo N, Sunpaweravong P, Han B, Margono B, Ichinose Y, Nishiwaki Y, Ohe Y, Yang JJ, Chewaskulyong B, Jiang H, Duffield EL, Watkins CL, Armour AA, Fukuoka M. Gefitinib or carboplatin-paclitaxel in pulmonary adenocarcinoma. N Engl J Med. 2009 Sep 3;361(10):947-57.

15. Natu S, Hoffman J, Siddiqui M, Hobday C, Shrimankar J, Harrison R. The role of endobronchial ultrasound guided transbronchial needle aspiration cytology in the investigation of mediastinal lymphadenopathy and masses, the North Tees experience. J Clin Pathol. 2010 May;63(5): 445-51.

Received: March 16, 2011 / Accepted: May 24, 2011

Address for correspondence:

Karl-Josef Franke, MD

Department of Pneumology and Critical Care Medicine

Helios Klinik Ambrock

University of Witten/Herdecke

Ambrocker Weg 60

58091 Hagen

Germany

Phone: 004923319742002

Fax: 004923319742009

E-mail: karl-josef.franke@helios-kliniken.de 